Article

\title{
$N$-(2,2-Dimethyl-1-(quinolin-2-yl)propylidene) arylaminonickel Complexes and Their Ethylene Oligomerization
}

\author{
Hongyi Suo ${ }^{1,2}$, Tong Zhao ${ }^{3}$, Yiqing Wang ${ }^{1}$, Qing Ban ${ }^{3, *}$ and Wen-Hua Sun ${ }^{1,2, *}$ \\ 1 Key Laboratory of Engineering Plastics and Beijing National Laboratory for Molecular Sciences, Institute of \\ Chemistry, Chinese Academy of Sciences, Beijing 100190, China; suohongyi@iccas.ac.cn (H.S.); \\ wyqing2015@126.com (Y.W.) \\ 2 CAS Research/Education Center for Excellence in Molecular Sciences, University of Chinese Academy of \\ Sciences, Beijing 100049, China \\ 3 School of Materials Science and Engineering, Qilu University of Technology, Jinan 250353, China; \\ zhaotong1218@163.com \\ * $\quad$ Correspondence: banqing@qlu.edu.cn (Q.B.); whsun@iccas.ac.cn (W.-H.S.); Tel.: +86-10-6255-7955 (W.-H.S.) \\ Academic Editor: Kotohiro Nomura \\ Received: 30 March 2017; Accepted: 11 April 2017; Published: 13 April 2017
}

\begin{abstract}
A series of N-(2,2-dimethyl-1-(quinolin-2-yl)propylidene) arylamines was sophisticatedly synthesized and reacted with nickel(II) bromine for the formation of the corresponding nickel complexes. All the organic compounds were characterized by IR, NMR spectra and elemental analysis, while all the nickel complexes were characterized by IR spectra and elemental analysis. On activation with ethylaluminium sesquichloride (EASC) and modified methylaluminoxane (MMAO), all nickel precatalysts exhibited good activities toward ethylene oligomerization, indicating the positive efficiency of gem-dimethyl substitutents; in which major hexenes were obtained with MMAO. The catalytic parameters were verified, and the steric and electronic influences of substituents with ligands were observed, with a slight change of activities under different ethylene pressures.
\end{abstract}

Keywords: nickel complex; $N$-(2,2-dimethyl-1-(quinolin-2-yl)propylidene) arylamine; ethylene oligomerization; schiff bases

\section{Introduction}

The discovery of diiminonickel halides (A, Figure 1) as high active precatalysts in ethylene reactivity symbolized a milestone of late-transition metal catalytic systems [1], and resurrected nickel chemistry in the petrochemical industry with regard to the Shell Higher Olefin Process (SHOP) using a nickel catalyst [2]. The fast development of nickel precatalysts have been reviewed in a number of reviews [3-5]. To enhance the catalytic performances of nickel precatalysts, one method has modified diimino-ligands with different substituents, especially bulkier ones [6-10], whilst another approach has designed alternative nickel precatalysts of model ligands, such as 2-(1-aryliminoethyl)pyridines (B, Figure 1) [11-15], 8-(1-aryliminoethyl)-5,6,7-trihydroquinolines (C, Figure 1) [16-20], 2-(1-aryliminoethyl) quinolines (D, Figure 1) [21], 8-benzothiazolylquinolines (E, Figure 1) [22] and tridentate 2-imino-1,10-phenanthrolines [23]. Principally, models of A [1,6-10], B [11-15] and C [16-20] are potential precatalysts toward ethylene polymerization; we extensively investigated and modified $\mathbf{C}$ through controlling the fused-ring numbers in five [24] and seven $[25,26]$ within their ligands, tailoring the resultant polyethylenes. There are few chances to tune models of $\mathbf{D}$ [21] and $\mathbf{E}$ [22]. However, encouraged with success of the gem-dimethylation for strained ligands [20,24], the 2,2-dimethyl-1-(quinolin-2-yl) propan-1-one was prepared and used to form $\mathrm{N}$-(2,2-dimethyl-1-(quinolin-2-yl)propylidene) arylamines and their nickel complexes (F, Figure 1). 
The title complexes exhibited high activities toward ethylene oligomerization, producing hexenes as the major product. Herein the synthesis and characterization of the title complexes are reported along with their ethylene oligomerization.

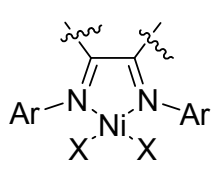

A<smiles>[X][Y]1([X])N([Al])C(C)=C2C=CC=CN21</smiles>

B

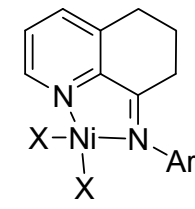

C<smiles>[X]C1([X])N([Al])C(C)=C2C=Cc3ccccc3N21</smiles>

D<smiles></smiles>

E<smiles>CC(C)(C)C1=NN([Al])C(Br)(Br)N2C=Cc3ccccc3N=C12</smiles>

F (this work)

Figure 1. Representative examples of geometry-constrained iminopyridylmetal precatalysts.

\section{Results}

\subsection{Synthesis and Characterization of Ligands and Nickel Complexes}

A series of $N$-(2,2-dimethyl-1-(quinolin-2-yl)propylidene) arylimines (L1-L5) was prepared in moderate yields by the Schiff base condensation of 2,2-dimethyl-1-(quinolin-2-yl)propan-1-one with anilines in the presence of a catalytic amount of p-toluenesulfonic acid. All of the organic compounds were routinely characterized by ${ }^{1} \mathrm{H}$ - and ${ }^{13} \mathrm{C}-\mathrm{NMR}$, FT-IR spectra, as well as elemental analysis. The addition of a 0.9 equivilent of (DME) $\mathrm{NiBr}_{2}$ (DME $=1$,2-dimethoxyethane) to a mixture solution involving dichloromethane and ethanol of the prepared ligands, respectively, resulted in the formation of the correspondent nickel complexes (Ni1-Ni5) in good yield (Scheme 1). All of the nickel complexes were characterized by FT-IR spectra and elemental analysis.

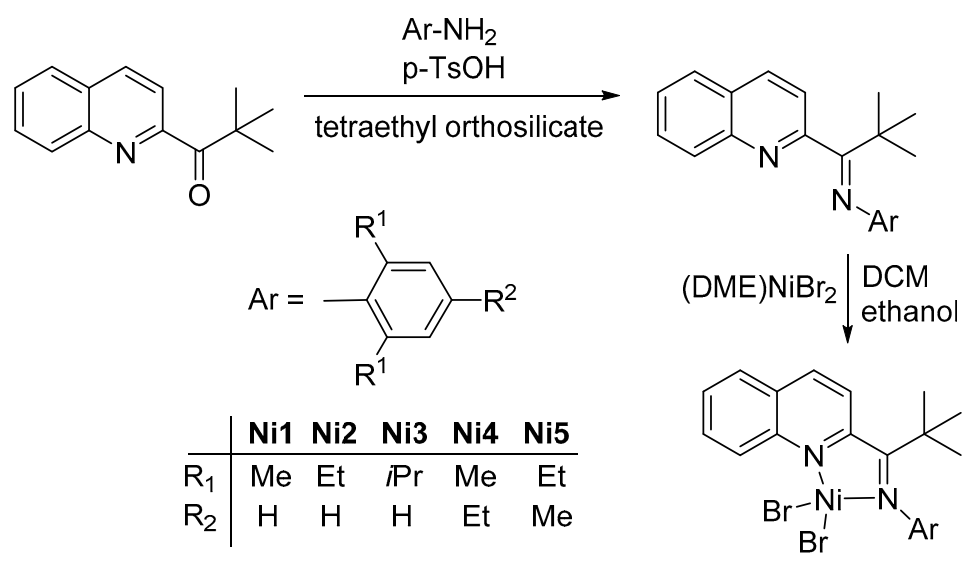

Scheme 1. Synthetic procedure for L1-L5 and Ni1-Ni5.

According to the FT-IR spectra, the stretching vibrations of the $v_{(\mathrm{C}=\mathrm{N})}$ in the abovementioned nickel complexes shifted to lower values $\left(1613-1629 \mathrm{~cm}^{-1}\right)$ with weaker intensity compared to those of the corresponding free ligands $\left(1633-1652 \mathrm{~cm}^{-1}\right)$, indicating the effective coordination between the $\mathrm{sp}^{2}$-nitrogen and the nickel atom.

\subsection{Ethylene Oligomerization}

In order to determine the most efficient co-catalyst for use in ethylene polymerization studies, as inspired by previous experiences of the [Al]/[Ni] molar ratios and reaction temperature [16-20], complex Ni1 was explored in toluene at $30^{\circ} \mathrm{C}$ with various co-catalysts such as methylaluminoxane (MAO), modified methylaluminoxane (MMAO), ethylaluminium sesquichloride (EASC, $\left.\mathrm{Et}_{3} \mathrm{Al}_{2} \mathrm{Cl}_{2}\right)$, diethylaluminium chloride $\left(\mathrm{Et}_{2} \mathrm{AlCl}\right)$ and triethylaluminium $\left(\mathrm{Et}_{3} \mathrm{Al}\right)$, respectively. Their results 
are tabulated in Table 1. Low activity was observed with both $\mathrm{Et}_{3} \mathrm{Al}$ or $\mathrm{MAO}$, producing mainly butenes. With the other three co-catalysts, the systems exhibited high activity in the range of $1.07 \times 10^{6}-1.33 \times 10^{6} \mathrm{~g} \mathrm{~mol}^{-1}(\mathrm{Ni}) \mathrm{h}^{-1}$. It is worth noting that there was a lower amount of butene observed in the use of MMAO and EASC, especially indicating major hexenes in the system with MMAO. Therefore, further studies were conducted with MMAO and EASC as co-catalysts.

Table 1. Effects of co-catalysts on ethylene reactivity ${ }^{a}$.

\begin{tabular}{|c|c|c|c|c|c|c|}
\hline \multirow{2}{*}{ Entry } & \multirow{2}{*}{ Co-Cat } & \multirow{2}{*}{$\mathrm{Al} / \mathrm{Ni}$} & \multirow{2}{*}{ Activity $b$} & \multicolumn{3}{|c|}{ Oligomer Distribution $^{c}(\%)$} \\
\hline & & & & $\mathrm{C}_{4} / \Sigma \mathrm{C}$ & $\mathrm{C}_{6} / \Sigma \mathrm{C}$ & $\mathrm{C}_{\geq 8} / \Sigma \mathrm{C}$ \\
\hline 1 & $\mathrm{Et}_{2} \mathrm{AlCl}$ & 400 & 1.07 & 55.0 & 42.1 & 2.9 \\
\hline 2 & EASC & 400 & 1.33 & 28.9 & 35.5 & 35.6 \\
\hline 3 & MAO & 1500 & 0.38 & 73.4 & 9.1 & 17.5 \\
\hline 4 & MMAO & 1500 & 1.25 & 9.1 & 87.1 & 3.8 \\
\hline 5 & $\mathrm{Et}_{3} \mathrm{Al}$ & 400 & 0.05 & 100 & & \\
\hline
\end{tabular}

a Reaction conditions: $3 \mu \mathrm{mol} \mathrm{Ni1}, 30 \mathrm{~min}, 30^{\circ} \mathrm{C}, 5$ atm ethylene, $100 \mathrm{~mL}$ toluene; ${ }^{\mathrm{b}} 10^{6} \mathrm{~g} \mathrm{~mol}^{-1}(\mathrm{Ni}) \mathrm{h}^{-1}$; ${ }^{\mathrm{c}}$ Determined by GC. $\Sigma \mathrm{C}$ denotes the total amount of oligomers.

\subsubsection{Ethylene Oligomerization in Presence of EASC}

The reaction parameters greatly affect the catalytic activity and, using EASC as a co-catalyst, we determined the optimal conditions of the oligomerization containing the $\mathrm{Al} / \mathrm{Ni}$ molar ratio, reaction temperature and run time. The results are collected in Table 2. Herein, Ni1 was typically screened for ethylene oligomerization reaction parameters at $5 \mathrm{~atm}$ ethylene pressure.

Table 2. Ethylene catalytic activity with Ni1-Ni5/EASC ${ }^{\text {a }}$.

\begin{tabular}{ccccccccc}
\hline \multirow{2}{*}{ Entry } & Cat. & \multirow{2}{*}{$\mathbf{A 1} / \mathbf{N i}$} & $\boldsymbol{t}(\mathbf{m i n})$ & $\mathbf{T}\left({ }^{\circ} \mathbf{C}\right)$ & Activity & \multicolumn{3}{c}{ Oligomer Distribution ${ }^{\mathbf{c}} \mathbf{( \% )}$} \\
\cline { 7 - 8 } & & & & & $\mathbf{C}_{\mathbf{4}} / \mathbf{\Sigma} \mathbf{C}$ & $\mathbf{C}_{\mathbf{6}} / \mathbf{\Sigma} \mathbf{C}$ & $\mathbf{C}_{\geq \mathbf{8}} / \mathbf{\Sigma} \mathbf{C}$ \\
\hline 1 & $\mathbf{N i 1}$ & 200 & 30 & 30 & 0.64 & 31.1 & 45.8 & 23.1 \\
2 & $\mathbf{N i 1}$ & 300 & 30 & 30 & 0.81 & 33.2 & 49.0 & 17.8 \\
3 & $\mathbf{N i 1}$ & 400 & 30 & 30 & 1.33 & 28.9 & 35.5 & 35.6 \\
4 & $\mathbf{N i 1}$ & 500 & 30 & 30 & 2.17 & 21.4 & 24.7 & 53.9 \\
5 & $\mathbf{N i 1}$ & 600 & 30 & 30 & 1.81 & 10.7 & 24.6 & 64.7 \\
6 & $\mathbf{N i 1}$ & 700 & 30 & 30 & 1.52 & 9.91 & 26.4 & 63.7 \\
7 & $\mathbf{N i 1}$ & 800 & 30 & 30 & 1.11 & 8.65 & 19.4 & 72.0 \\
8 & $\mathbf{N i 1}$ & 500 & 30 & 20 & 1.38 & 29.5 & 22.6 & 47.9 \\
9 & $\mathbf{N i 1}$ & 500 & 30 & 40 & 3.34 & 15.7 & 22.9 & 61.4 \\
10 & $\mathbf{N i 1}$ & 500 & 30 & 50 & 2.78 & 10.2 & 18.8 & 71.0 \\
11 & $\mathbf{N i 1}$ & 500 & 30 & 60 & 2.49 & 8.20 & 15.1 & 76.7 \\
12 & $\mathbf{N i 1}$ & 500 & 15 & 40 & 5.99 & 16.8 & 18.1 & 65.1 \\
13 & $\mathbf{N i 1}$ & 500 & 45 & 40 & 3.15 & 14.7 & 25.6 & 59.7 \\
14 & $\mathbf{N i 1}$ & 500 & 60 & 40 & 3.01 & 16.0 & 26.3 & 57.7 \\
15 & $\mathbf{N i 2}$ & 500 & 30 & 40 & 4.06 & 15.1 & 16.3 & 68.6 \\
16 & $\mathbf{N i 3}$ & 500 & 30 & 40 & trace & & & \\
17 & $\mathbf{N i 4}$ & 500 & 30 & 40 & 3.03 & 16.5 & 20.1 & 63.4 \\
18 & $\mathbf{N i 5}$ & 500 & 30 & 40 & 3.90 & 16.8 & 18.8 & 64.4 \\
19 & $\mathbf{N i 1}$ & 500 & 30 & 40 & 3.91 & 18.7 & 26.0 & 55.3 \\
\hline
\end{tabular}

a Reaction conditions: $3 \mu \mathrm{mol} \mathrm{Ni1,} 5$ atm ethylene, $100 \mathrm{~mL}$ toluene; ${ }^{\mathrm{b}} 10^{6} \mathrm{~g} \mathrm{~mol}^{-1}\left(\mathrm{Ni}^{2} \mathrm{~h}^{-1}\right.$; $^{\mathrm{c}}$ Determined by GC. $\Sigma \mathrm{C}$ denotes the total amount of oligomers; ${ }^{\mathrm{d}} 10 \mathrm{~atm}$.

Firstly, with the temperature at $30{ }^{\circ} \mathrm{C}$ and the run time set at $30 \mathrm{~min}$, increasing the $\mathrm{Al} / \mathrm{Ni}$ molar ratio from 200 to 500 resulted in an increase trend, with the highest activity of $2.17 \times 10^{6} \mathrm{~g} \mathrm{~mol}^{-1}(\mathrm{Ni}) \mathrm{h}^{-1}$ observed at an $\mathrm{Al} / \mathrm{Ni}$ molar ratio of 500 (entries 1-4, Table 2). Subsequently, as the molar ratio still aggrandized, the activity gradually decreased down to $1.11 \times 10^{6} \mathrm{~g} \mathrm{~mol}^{-1}\left(\mathrm{Ni}^{-1} \mathrm{~h}^{-1}\right.$ (entries 5-7, Table 2). This suggested that the enlargement of the $\mathrm{Al} / \mathrm{Ni}$ molar ratio results in the rate of chain termination exceeding the rate of chain propagation, thus forming longer chain oligomers. 
$\mathrm{Next}$, with the $\mathrm{Al} / \mathrm{Ni}$ molar ratio fixed at 500 with $30 \mathrm{~min}$, the activity for ethylene oligomerization was substantially affected by the changes of reaction temperature (entries 4 and 8-11, Table 2). On increasing the temperature from $20^{\circ} \mathrm{C}$ to $60^{\circ} \mathrm{C}$, the activity was initially increased to a summit with $3.34 \times 10^{6} \mathrm{~g} \mathrm{~mol}^{-1}(\mathrm{Ni}) \mathrm{h}^{-1}$ observed at $40^{\circ} \mathrm{C}$, and the value subsequently went down. This drop in catalytic performance along with the increasing temperature was assigned to the partial deactivation of the active species when the temperature was elevated. The substance of the oligomeric proportions was stochastically changed, implying that the reaction temperature did not effectively control the rate of chain propagation to $\beta$-hydrogen elimination. A similar influence of temperature on oligomer distribution using nickel-based systems has previously been reported by our group $[23,27,28]$.

Thirdly, the optimized condition with the $\mathrm{Al} / \mathrm{Ni}$ molar ratio equal to 500 at $40{ }^{\circ} \mathrm{C}$ was used to choose the best run time. The results revealed that the highest activity of $5.99 \times 10^{6} \mathrm{~g} \mathrm{~mol}^{-1}(\mathrm{Ni}) \mathrm{h}^{-1}$ was observed at $15 \mathrm{~min}$, which disclosed that this oligomerization did not have induction time. It was uncommon to observe longer oligomers produced in a shorter period; the portion of $\mathrm{C}_{\geq 8}$ within $15 \mathrm{~min}$ (entry 12, Table 2) was more than those in $30 \mathrm{~min}$ (entry 9, Table 2), which was more than those in 45 min (entry 13, Table 2), and more than those in 60 min (entry 14, Table 2); such phenomena could be interpreted as the regenerated active species producing shorter oligomers. To have less error caused by operating period, so we finally selected $30 \mathrm{~min}$ as the optimized condition.

Under the optimum condition selected by the catalytic system of Ni1/EASC, all pre-catalysts Ni1-Ni5 were investigated for ethylene oligomerization in order to elucidate the influence of the ligand structure. The results are summarized in Table 2 (entries 9 and 15-18). Although Ni3 [2,6-di(iPr)] did not show much activity, other nickel complexes exhibited good activity results, especially Ni2, which showed the highest activity among all five catalysts at $4.06 \times 10^{6} \mathrm{~g} \mathrm{~mol}^{-1}(\mathrm{Ni}) \mathrm{h}^{-1}$. Getting rid of the inactive $\mathrm{Ni3}$, the other nickel pro-catalysts exhibited high activities and varied in the order: Ni2 [2,6-di(Et)] > Ni1 [2,6-di(Me)], Ni5 [2,6-di(Et)-4-(Me)] > Ni4 [2,4,6-tri(Me)]. The catalytic properties were affected by both the steric and electronic effects of the substituent of the ligands. It is possible that the groups with greater bulkiness at the ortho position of the $\mathrm{N}$-imino aryl ring may protect the active sites from deactivation. The bulkier the $\mathrm{R}^{1}$ is, the higher the activity was observed. For example, the activity of $\mathbf{N i 2}\left(4.06 \times 10^{6} \mathrm{~g} \mathrm{~mol}^{-1}(\mathrm{Ni}) \mathrm{h}^{-1}\right)$ is greater than that of $\mathbf{N i 1}\left(3.34 \times 10^{6} \mathrm{~g} \mathrm{~mol}^{-1}(\mathrm{Ni}) \mathrm{h}^{-1}\right)$, as well as the similar trend in Ni5 $\left(3.90 \times 10^{6} \mathrm{~g} \mathrm{~mol}^{-1}(\mathrm{Ni}) \mathrm{h}^{-1}\right)$ exceeded that of $\mathrm{Ni3}\left(3.03 \times 10^{6} \mathrm{~g} \mathrm{~mol}^{-1}\right.$ $\left.(\mathrm{Ni}) \mathrm{h}^{-1}\right)$. Furthermore, the presence of the additional electron-donating methyl group at 4-position of the aryl ring enhanced the solubility, which can be helpful to activate the complex. However, the existence of methyl group at para position resulted in a reduction in activity, due to the lower net charge at the nickel center. So, Ni2 $>$ Ni5 and Ni1 $>$ Ni4 can be reasonably explained [29-31]. In comparison with nickel, iron and cobalt analogs bearing 2-(1-aryliminoethylidene) quinoline [21], which have structures similar to the pre-catalysts examined here, the current series of nickel pre-catalysts showed nearly ten times higher activity for ethylene oligomerization due to the bulkier propyl group attached to the imide carbon, which might stabilize the catalytic center. Thus, these similar series of pre-catalysts with nickel centers are of greater activity than the iron and cobalt ones.

\subsubsection{Ethylene Oligomerization in Presence of MMAO}

In a similar procedure, the catalytic system using MMAO as a co-catalyst was studied systematically, and the results are summarized in Table 3 . When the $\mathrm{Al} / \mathrm{Ni}$ molar ratio was fixed at 2500, the Ni1/MMAO system exhibited the best activity $\left(1.71 \times 10^{6} \mathrm{~g} \mathrm{~mol}^{-1}(\mathrm{Ni}) \mathrm{h}^{-1}\right)$, and oligomerization activity decreased gradually when the $\mathrm{Al} / \mathrm{Ni}$ molar ratio were raised or lowered (entries 1-5, Table 3). Under the optimum $\mathrm{Al} / \mathrm{Ni}$ molar ratio, the activities initially increased and then gradually decreased when the temperature was elevated from $20{ }^{\circ} \mathrm{C}$ to $60{ }^{\circ} \mathrm{C}$, with the highest activity observed at $1.75 \times 10^{6} \mathrm{~g} \mathrm{~mol}^{-1}(\mathrm{Ni}) \mathrm{h}^{-1}$ at $40{ }^{\circ} \mathrm{C}$ (entries 3 and 6-9, Table 3). This phenomenon is consistent with the decomposition of catalysts and a lower absorption of ethylene in the solution at higher temperatures. Differing from the Ni1/EASC system, when MMAO used as a co-catalyst the active life 
of the pre-catalyst was shorter as the activity decreased sharply with longer run times (entries 7 and 10-12, Table 3).

Table 3. Ethylene catalytic activity with Ni1-Ni5/MMAO ${ }^{\mathrm{a}}$.

\begin{tabular}{|c|c|c|c|c|c|c|c|c|}
\hline \multirow{2}{*}{ Entry } & \multirow{2}{*}{ Cat. } & \multirow{2}{*}{$\mathbf{A l} / \mathbf{N i}$} & \multirow{2}{*}{$t(\min )$} & \multirow{2}{*}{$\mathrm{T}\left({ }^{\circ} \mathrm{C}\right)$} & \multirow{2}{*}{ Activity ${ }^{b}$} & \multicolumn{3}{|c|}{ Oligomer Distribution $^{c}(\%)$} \\
\hline & & & & & & $\mathrm{C}_{4} / \Sigma \mathrm{C}$ & $\mathrm{C}_{6} / \Sigma \mathrm{C}$ & $\mathrm{C}_{\geq 8} / \Sigma \mathrm{C}$ \\
\hline 1 & Ni1 & 1000 & 30 & 30 & 1.10 & 9.1 & 80.8 & 10.1 \\
\hline 2 & Ni1 & 2000 & 30 & 30 & 1.45 & 8.9 & 78.1 & 13.0 \\
\hline 3 & Ni1 & 2500 & 30 & 30 & 1.71 & 7.6 & 75.7 & 16.7 \\
\hline 4 & Ni1 & 3000 & 30 & 30 & 1.63 & 6.7 & 71.4 & 21.9 \\
\hline 5 & Ni1 & 3500 & 30 & 30 & 1.54 & 9.0 & 73.1 & 17.9 \\
\hline 6 & Ni1 & 2500 & 30 & 20 & 1.52 & 9.7 & 81.3 & 9.0 \\
\hline 7 & Ni1 & 2500 & 30 & 40 & 1.75 & 7.8 & 88.4 & 3.8 \\
\hline 8 & Ni1 & 2500 & 30 & 50 & 1.67 & 6.8 & 88.9 & 4.3 \\
\hline 9 & Ni1 & 2500 & 30 & 60 & 1.49 & 5.2 & 90.0 & 4.8 \\
\hline 10 & Ni1 & 2500 & 15 & 40 & 3.18 & 8.8 & 88.1 & 3.1 \\
\hline 11 & Ni1 & 2500 & 45 & 40 & 0.89 & 6.7 & 88.9 & 4.4 \\
\hline 12 & Ni1 & 2500 & 60 & 40 & 0.68 & 6.0 & 90.5 & 3.5 \\
\hline 13 & $\mathrm{Ni} 2$ & 2500 & 30 & 40 & 1.81 & 7.5 & 86.9 & 5.6 \\
\hline 14 & $\mathrm{Ni4}$ & 2500 & 30 & 40 & 1.50 & 5.9 & 89.7 & 4.4 \\
\hline 15 & Ni5 & 2500 & 30 & 40 & 1.65 & 8.1 & 83.4 & 8.5 \\
\hline $16^{\mathrm{d}}$ & Ni1 & 2500 & 30 & 40 & 1.91 & 8.7 & 89.0 & 2.3 \\
\hline
\end{tabular}

${ }^{a}$ Reaction conditions: $3 \mu \mathrm{mol} \mathrm{Ni1,} 5$ atm ethylene, $100 \mathrm{~mL}$ toluene; ${ }^{\mathrm{b}} 10^{6} \mathrm{~g} \mathrm{~mol}^{-1}(\mathrm{Ni}) \mathrm{h}^{-1}$; $^{\mathrm{c}}$ Determined by GC. $\Sigma \mathrm{C}$ denotes the total amount of oligomers; ${ }^{\mathrm{d}} 10 \mathrm{~atm}$.

The influence of the ligand properties of the catalyst on oligomerization activities and their oligomer distributions with MMAO as co-catalyst was investigated under the optimum reaction conditions of $\mathrm{Al} / \mathrm{Ni}$ molar ratio at $2500: 1$ at $40{ }^{\circ} \mathrm{C}$ with $30 \mathrm{~min}$ run time. Same as the EASC co-catalyst system, the activity order of Ni2 $>$ Ni1, Ni5 $>$ Ni4 was also observed using MMAO as the co-catalyst. Though the catalytic activity of the Ni/MMAO system was lower than that of the Ni/EASC system, more ethylene trimer was obtained, which exhibited a good selectivity in producing hexenes. Of course, this result greatly inspired us to design other catalysts with good selectivity as well as guided us toward the co-catalyst chosen in further studies. Unfortunately, the mechanism resulting in ethylene trimerization is still under exploration.

\section{Materials and Methods}

\subsection{General Considerations}

All manipulations involving air and moisture-sensitive compounds were carried out under an atmosphere of purified nitrogen using standard Schlenk. Toluene was dried over sodium metal and distilled under nitrogen. Methylaluminoxane (MAO, $1.46 \mathrm{M}$ solution in toluene) and modified methylaluminoxane (MMAO, 1.93 M in heptane) were purchased from Akzo Nobel Corp. (Nanjing, China). Diethylaluminium chloride $\left(\mathrm{Et}_{2} \mathrm{AlCl}, 1.17 \mathrm{M}\right.$ in hexane) and ethylaluminium sesquichloride (EASC, $0.87 \mathrm{M}$ in hexane), triethylaluminium ( $\mathrm{Et}_{3} \mathrm{Al}, 2.00 \mathrm{M}$ in heptane) and other reagents were purchased from Acros Chemicals (Beijing, China). (DME) $\mathrm{NiBr}_{2}$ was synthesized by the reaction of 1,2-dimethoxyethane with anhydrous nickel(II) bromide. FT-IR spectra were recorded on a Perkine-Elmer System 2000 FT-IR spectrometer (Shanghai, China). Elemental analysis was carried out using a Flash EA 1112 microanalyzer (Beijing, China). ${ }^{1} \mathrm{H}$ - and ${ }^{13} \mathrm{C}-\mathrm{NMR}$ spectra were recorded on a Bruker DMX $400 \mathrm{MHz}$ instrument (Beijing, China) at ambient temperature using tetramethylsilane (TMS) as an internal standard. GC analyses were performed with a Varian CP-3800 gas chromatograph (Beijing, China) equipped with a flame ionization detector and a $30 \mathrm{~m}(0.2 \mathrm{~mm}$ i.d., $0.25 \mathrm{~mm}$ film thickness) CP-Sil 5 CB column. 


\subsection{Synthesis and Characterization of Ligands}

N-(2,2-Dimethyl-1-(quinolin-2-yl)propylidene)-2,6-dimethylbenzenamine (L1). Similar to our previously work, a mixture of tert-butyl 2-quinolyl ketone ( $0.64 \mathrm{~g}, 3 \mathrm{mmol}), 2,6$-dimethylaniline $(0.52 \mathrm{~g}, 3 \mathrm{mmol})$ and a catalytic amount of $p$-toluenesulfonic acid in tetraethyl orthosilicate $(100 \mathrm{~mL})$ was refluxed for $24 \mathrm{~h}$. The solvent was rotary evaporated and the crude product was purified by column chromatography on silica gel (500:5:1 $(v / v / v)$ petroleum ether/ethyl acetate/triethylamine) to give the product as a yellow solid in 63\% yield. IR $\left(\mathrm{KBr}, \mathrm{cm}^{-1}\right): 2963(\mathrm{~m}), 2866(\mathrm{w}), 1652(\mathrm{~s}), 1589(\mathrm{~m})$, 1489 (m), 1462 (s), 1357 (m), 1083 (w), 986 (s), 829 (s), 762 (s). ${ }^{1} \mathrm{H}-\mathrm{NMR}\left(\mathrm{CDCl}_{3}, 400 \mathrm{MHz}, \mathrm{TMS}\right)$ : $8.05(\mathrm{~d}, J=8.8 \mathrm{~Hz}, 1 \mathrm{H}$, quinoline), $7.83(\mathrm{~d}, J=8.4 \mathrm{~Hz}, 1 \mathrm{H}$, quinoline), $7.66(\mathrm{t}, J=7.0 \mathrm{~Hz}, 2 \mathrm{H}$, quinoline), $7.46(\mathrm{t}, J=7.2 \mathrm{~Hz}, 1 \mathrm{H}$, quinoline), $6.87(\mathrm{~d}, J=8.4 \mathrm{~Hz}, 1 \mathrm{H}$, quinoline), $6.75(\mathrm{~d}, J=7.2 \mathrm{~Hz}, 2 \mathrm{H}, m-\mathrm{Ar})$, $6.63(\mathrm{t}, J=7.4 \mathrm{~Hz}, 1 \mathrm{H}, p-\mathrm{Ar}), 2.16\left(\mathrm{~s}, 6 \mathrm{H},-\mathrm{CH}_{3}\right), 1.46\left(\mathrm{~s}, 9 \mathrm{H},-\mathrm{CH}_{3}\right) .{ }^{13} \mathrm{C}-\mathrm{NMR}\left(\mathrm{CDCl}_{3}, 100 \mathrm{MHz}, \mathrm{TMS}\right)$ : 177.4, 157.1, 148.2, 147.2, 135.0, 129.9, 129.5, 127.7, 127.6, 127.1, 126.8, 126.0, 122.6, 119.3, 40.9, 29.2, 18.6. Anal. Calc. for $\mathrm{C}_{22} \mathrm{H}_{24} \mathrm{~N}_{2}$ (316.44): C, 83.50; H, 7.58; N, 8.85\%. Found: C, 83.34; H, 7.74; N, 8.69\%.

$N$-(2,2-Dimethyl-1-(quinolin-2-yl)propylidene)-2,6-diethylbenzenamine (L2). In a manner similar to that described for L1, L2 was prepared as a yellow solid in 67\% yield. IR $\left(\mathrm{KBr}, \mathrm{cm}^{-1}\right): 2965(\mathrm{~m}), 2872(\mathrm{~m})$, 1644 (s), 1593 (s), 1499 (m), 1454 (m), 1364 (w), 1041 (s), 830 (s), 755 (s). ${ }^{1} \mathrm{H}-\mathrm{NMR}$ (CDCl, $400 \mathrm{MHz}$, TMS): $8.06(\mathrm{~d}, J=8.4 \mathrm{~Hz}, 1 \mathrm{H}$, quinoline), 7.81 (d, $J=8.4 \mathrm{~Hz}, 1 \mathrm{H}$, quinoline), 7.68-7.64 (m, 2H, quinoline), 7.49-7.45 (m, 1H, quinoline), $6.88(\mathrm{~d}, J=8.4 \mathrm{~Hz}, 1 \mathrm{H}$, quinoline), $6.83(\mathrm{~d}, J=7.2 \mathrm{~Hz}, 2 \mathrm{H}, m-\mathrm{Ar}), 6.77-6.74$ (m, 1H, p-Ar), 2.76-2.67 (m, 2H, - $\left.\mathrm{CH}_{2}-\right), 2.45-2.37\left(\mathrm{~m}, 2 \mathrm{H},-\mathrm{CH}_{2}-\right), 1.48\left(\mathrm{~s}, 9 \mathrm{H},-\mathrm{CH}_{3}\right), 1.21(\mathrm{t}, J=7.6 \mathrm{~Hz}$, 6H, $\left.-\mathrm{CH}_{3}\right) .{ }^{13} \mathrm{C}-\mathrm{NMR}\left(\mathrm{CDCl}_{3}, 100 \mathrm{MHz}, \mathrm{TMS}\right): 176.2,156.8,147.2,147.1,134.8,131.4,129.8,129.3,127.5$, $126.9,126.6,125.2,122.7,119.3,40.9,29.0,24.6,13.4$. Anal. Calc. for $\mathrm{C}_{24} \mathrm{H}_{28} \mathrm{~N}_{2}$ (344.50): C, 83.67; $\mathrm{H}, 8.13$; N, 8.13\%. Found: C, 83.87; H, 8.34; N, 8.01\%.

$\mathrm{N}$-(2,2-Dimethyl-1-(quinolin-2-yl)propylidene)-2,6-diisopropylbenzenamine (L3). In a manner similar to that described for L1, L3 was prepared as a yellow solid in 54\% yield. IR $\left(\mathrm{KBr}, \mathrm{cm}^{-1}\right): 2959(\mathrm{~m})$, $2920(\mathrm{~m}), 1636(\mathrm{~m}), 1590(\mathrm{w}), 1499(\mathrm{w}), 1463(\mathrm{~m}), 1358(\mathrm{~m}), 1040$ (s), 1001 (m), 825 (s), 752 (s). ${ }^{1} \mathrm{H}-\mathrm{NMR}$ ( $\left.\mathrm{CDCl}_{3}, 400 \mathrm{MHz}, \mathrm{TMS}\right): 8.01(\mathrm{~d}, J=8.8 \mathrm{~Hz}, 1 \mathrm{H}$, quinoline), $7.81(\mathrm{~d}, J=8.8 \mathrm{~Hz}, 1 \mathrm{H}$, quinoline), 7.65-7.62 (m, 2H, quinoline), $7.45(\mathrm{t}, J=7.6 \mathrm{~Hz}, 1 \mathrm{H}$, quinoline), 6.84-6.82 (m, 3H), 6.79-6.75 (m, $1 \mathrm{H}, p-\mathrm{Ar})$, 3.16-3.09 (m, 2H, -CH-), $1.44\left(\mathrm{~s}, 9 \mathrm{H},-\mathrm{CH}_{3}\right), 1.14\left(\mathrm{~d}, J=6.4 \mathrm{~Hz}, 6 \mathrm{H},-\mathrm{CH}_{3}\right), 1.05\left(\mathrm{~d}, J=6.8 \mathrm{~Hz}, 6 \mathrm{H},-\mathrm{CH}_{3}\right)$. ${ }^{13} \mathrm{C}-\mathrm{NMR}\left(\mathrm{CDCl}_{3}, 100 \mathrm{MHz}\right.$, TMS): 175.5, 156.8, 147.1, 145.9, 135.7, 134.6, 129.7, 129.3, 127.4, 126.8, 126.5, 122.7, 122.1, 119.3, 40.8, 29.0, 28.2, 23.6, 21.6. Anal. Calc. for $\mathrm{C}_{26} \mathrm{H}_{32} \mathrm{~N}_{2}$ (372.56): C, 83.82; $\mathrm{H}, 8.60$; N, 7.52\%. Found: C, 83.65; H, 8.81; N, 7.58\%.

N-(2,2-Dimethyl-1-(quinolin-2-yl)propylidene)mesitylamine (L4). In a manner similar to that described for L1, L4 was prepared as a yellow solid in 54\% yield. IR (KBr, cm $\left.{ }^{-1}\right): 2965(\mathrm{~m}), 2915(\mathrm{~m}), 1680(\mathrm{w})$, 1633 (s), 1594 (m), 1499 (m), 1469 (s), 1358 (m), 1000 (m), 827 (s), 748 (s). ${ }^{1} \mathrm{H}-\mathrm{NMR}$ (CDCl ${ }_{3}, 400 \mathrm{MHz}$, TMS): $8.06(\mathrm{~d}, J=8.8 \mathrm{~Hz}, 1 \mathrm{H}$, quinoline), $7.83(\mathrm{~d}, J=8.8 \mathrm{~Hz}, 1 \mathrm{H}$, quinoline), 7.68-7.65 (m, 2H, quinoline), $7.47(\mathrm{t}, J=7.6 \mathrm{~Hz}, 1 \mathrm{H}$, quinoline), $6.86(\mathrm{~d}, J=8.4 \mathrm{~Hz}, 1 \mathrm{H}$, quinoline), $6.56(\mathrm{~s}, 2 \mathrm{H}, m-\mathrm{Ar}), 2.11(\mathrm{~s}, 6 \mathrm{H}$, $\left.-\mathrm{CH}_{3}\right), 2.05\left(\mathrm{~s}, 3 \mathrm{H},-\mathrm{CH}_{3}\right), 1.44\left(\mathrm{~s}, 9 \mathrm{H},-\mathrm{CH}_{3}\right) .{ }^{13} \mathrm{C}-\mathrm{NMR}\left(\mathrm{CDCl}_{3}, 100 \mathrm{MHz}, \mathrm{TMS}\right): 177.3,157.2,147.1$, 145.5, 134.9, 131.5, 129.8, 129.3, 128.1, 127.5, 126.9, 125.6, 119.3, 40.8, 29.0, 20.6, 18.4. Anal. Calc. for $\mathrm{C}_{23} \mathrm{H}_{26} \mathrm{~N}_{2}$ (330.48): $\mathrm{C}, 83.58 ; \mathrm{H}, 7.87 ; \mathrm{N}, 8.47 \%$. Found: $\mathrm{C}, 83.34 ; \mathrm{H}, 7.69 ; \mathrm{N}, 8.58 \%$.

N-(2,2-Dimethyl-1-(quinolin-2-yl)propylidene)-2,6-diethyl-4-methylbenzenamine (L5). In a manner similar to that described for L1, L5 was prepared as a yellow solid in $37 \%$ yield. IR $\left(\mathrm{KBr}, \mathrm{cm}^{-1}\right): 2975(\mathrm{w})$, $1683(\mathrm{w}), 1642$ (s), $1594(\mathrm{~m}), 1500(\mathrm{~m}), 1462$ (m), 1142 (m), 1038 (s), 818 (s), 799 (s). ${ }^{1} \mathrm{H}-\mathrm{NMR}\left(\mathrm{CDCl}_{3}\right.$, $400 \mathrm{MHz}, \mathrm{TMS}): 8.04(\mathrm{~d}, J=8.8 \mathrm{~Hz}, 1 \mathrm{H}$, quinoline), $7.81(\mathrm{~d}, J=8.8 \mathrm{~Hz}, 1 \mathrm{H}$, quinoline), 7.67-7.64 $(\mathrm{m}, 2 \mathrm{H}$, quinoline), $7.46(\mathrm{t}, J=7.6 \mathrm{~Hz}, 1 \mathrm{H}$, quinoline), $6.85(\mathrm{~d}, J=8.4 \mathrm{~Hz}, 1 \mathrm{H}$, quinoline), $6.60(\mathrm{~s}, 2 \mathrm{H}, m-\mathrm{Ar})$, 2.69-2.60 (m, 2H, $\left.-\mathrm{CH}_{2}-\right), 2.35-2.28\left(\mathrm{~m}, 2 \mathrm{H},-\mathrm{CH}_{2}-\right), 2.10\left(\mathrm{~s}, 3 \mathrm{H},-\mathrm{CH}_{3}\right), 1.43\left(\mathrm{~s}, 9 \mathrm{H},-\mathrm{CH}_{3}\right), 1.15(\mathrm{t}, J=7.4 \mathrm{~Hz}$, $\left.6 \mathrm{H},-\mathrm{CH}_{3}\right) .{ }^{13} \mathrm{C}-\mathrm{NMR}\left(\mathrm{CDCl}_{3}, 100 \mathrm{MHz}, \mathrm{TMS}\right): 175.2,156.0,146.0,143.5,133.7,130.5,130.1,128.7,128.1$, 126.4, 125.8, 125.4, 124.8, 118.4, 39.8, 27.9, 23.5, 19.8, 12.4. Anal. Calc. for $\mathrm{C}_{25} \mathrm{H}_{30} \mathrm{~N}_{2}$ (358.53): C, 83.74; $\mathrm{H}, 8.37$; N, 7.81\%. Found: C, 83.52; H, 8.54; N, 7.62\%. 


\subsection{Synthesis and Characterization of Nickel Complexes}

N-(2,2-Dimethyl-1-(quinolin-2-yl)propylidene)-2,6-dimethylbenzenaminonickel dichloride (Ni1). To add the ligand $\mathrm{N}$-(2,2-dimethyl-1-(quinolin-2-yl)propylidene)-2,6-dimethyl-benzenamine ( $0.32 \mathrm{~g}, 1 \mathrm{mmol})$ in a mixed solution of dichloromethane $(5 \mathrm{~mL})$ and ethanol $(5 \mathrm{~mL}),(\mathrm{DME}) \mathrm{NiBr}_{2}(0.28 \mathrm{~g}, 0.9 \mathrm{mmol})$ was added. The mixture was stirred at room temperature for $24 \mathrm{~h}$ to afford a brown precipitate from the reaction mixture. The resulted precipitate was filtered and washed with diethyl ether $(3 \times 5 \mathrm{~mL})$ to afford a brown powder $(0.28 \mathrm{~g}, 0.52 \mathrm{mmol})$ in $59 \%$ yield. IR $\left(\mathrm{KBr}, \mathrm{cm}^{-1}\right)$ : $2981(\mathrm{w}), 2917(\mathrm{w})$, $1619(\mathrm{w}), 1591$ (s), $1508(\mathrm{~m}), 1459(\mathrm{~m}), 1173(\mathrm{~s}), 1060(\mathrm{w}), 958(\mathrm{~m}), 866(\mathrm{w}), 833$ (s), 753 (s). Anal. Calc. for $\mathrm{C}_{22} \mathrm{H}_{24} \mathrm{Br}_{2} \mathrm{~N}_{2} \mathrm{Ni}$ (534.94): C, 49.39; H, 4.49; N, 5.23\%. Found: $\mathrm{C}, 49.68 ; \mathrm{H}, 4.67 ; \mathrm{N}, 5.11 \%$.

N-(2,2-Dimethyl-1-(quinolin-2-yl)propylidene)-2,6-diethylbenzenaminonickel dichloride (Ni2). Using a similar procedure as that described for the synthesis of Ni1, Ni2 was obtained in $63 \%$ yield. IR $\left(\mathrm{KBr}, \mathrm{cm}^{-1}\right)$ : $2972(\mathrm{~m}), 1617(\mathrm{w}), 1505(\mathrm{w}), 1454(\mathrm{~m}), 1383(\mathrm{w}), 1344(\mathrm{w}), 1167$ (m), $1064(\mathrm{~m}), 1006(\mathrm{~m}), 832(\mathrm{w}), 790(\mathrm{~m})$, 757 (s), 722 (m). Anal. Calc. for $\mathrm{C}_{24} \mathrm{H}_{28} \mathrm{Br}_{2} \mathrm{~N}_{2} \mathrm{Ni}$ (562.99): C, 51.20; H, 4.97; N, 4.97\%. Found: C, 51.42; $\mathrm{H}, 5.12 ; \mathrm{N}, 4.76 \%$.

$\mathrm{N}$-(2,2-Dimethyl-1-(quinolin-2-yl)propylidene)-2,6-diisopropylbenzenaminonickel dichloride (Ni3). Using a similar procedure as that described for the synthesis of Ni1, Ni3 was obtained in $63 \%$ yield. IR (KBr, cm $\left.{ }^{-1}\right)$ : $2947(\mathrm{~m}), 1621(\mathrm{w}), 1456(\mathrm{w}), 1388(\mathrm{w}), 1351$ (s), $1094(\mathrm{~s}), 1001$ (s), $800(\mathrm{w})$. Anal. Calc. for $\mathrm{C}_{26} \mathrm{H}_{32} \mathrm{Br}_{2} \mathrm{~N}_{2} \mathrm{Ni}$ (591.06): C, 52.83; H, 5.41; N, 4.74\%. Found: $\mathrm{C}, 52.98 ; \mathrm{H}, 5.72 ; \mathrm{N}, 4.58 \%$.

N-(2,2-Dimethyl-1-(quinolin-2-yl)propylidene)mesitylaminonickel dichloride (Ni4). Using a similar procedure as that described for the synthesis of Ni1, Ni4 was obtained in $63 \%$ yield. IR $\left(\mathrm{KBr}, \mathrm{cm}^{-1}\right)$ : $2912(\mathrm{~m}), 1629(\mathrm{w}), 1590(\mathrm{~s}), 1506(\mathrm{~m}), 1463(\mathrm{~m}), 1385(\mathrm{w}), 1140(\mathrm{w}), 1004(\mathrm{~m}), 960(\mathrm{w}), 833(\mathrm{~m}), 760(\mathrm{~s})$. Anal. Calc. for $\mathrm{C}_{23} \mathrm{H}_{26} \mathrm{Br}_{2} \mathrm{~N}_{2} \mathrm{Ni}$ (548.98): C, 50.32; H, 4.74; N, 5.10\%. Found: C, 50.20; H, 4.98; N, 4.89\%.

N-(2,2-Dimethyl-1-(quinolin-2-yl)propylidene)-2,6-diethyl-4-methylbenzenaminonickel dichloride (Ni5). Using a similar procedure as that described for the synthesis of Ni1, Ni5 was obtained in $63 \%$ yield. IR (KBr, cm ${ }^{-1}$ ): $2974(\mathrm{~m}), 1613$ (w), 1591 (m), 1508 (m), 1456 (s), 1387 (m), $1134(\mathrm{w}), 1007$ (m), 955 (w), 836 (s), 763 (s). Anal. Calc. for $\mathrm{C}_{25} \mathrm{H}_{30} \mathrm{Br}_{2} \mathrm{~N}_{2} \mathrm{Ni}$ (577.03): C, 52.03; $\mathrm{H}, 5.20 ; \mathrm{N}, 4.85 \%$. Found: $\mathrm{C}, 52.26$; $\mathrm{H}, 5.31 ; \mathrm{N}, 4.66 \%$.

\subsection{General Procedure for Ethylene Oligomerization}

Ethylene oligomerization at $5 \mathrm{~atm}$ ethylene pressure was performed in a stainless steel autoclave (250 mL capacity) equipped with gas ballast through a solenoid clave for the continuous feeding of ethylene at a constant pressure. Twenty milliliters of toluene was added into the autoclave under ethylene atmosphere and the catalyst precursor was dissolved in $30 \mathrm{~mL}$ toluene in a Schlenk tube, stirred with a magnetic stirrer and injected into the reactor. With the desired amount of EASC or MMAO, $50 \mathrm{~mL}$ toluene (total volume was $100 \mathrm{~mL}$ ) was added. When the reaction temperature had been reached, ethylene at the desired pressure was introduced to start the reaction. After stirring for the desired period of time, the reaction was stopped and about $2 \mathrm{~mL}$ of the reaction solution was collected and terminated by the addition of $4 \mathrm{~mL} \mathrm{10 \%} \mathrm{aqueous} \mathrm{hydrogen} \mathrm{chloride.} \mathrm{The} \mathrm{organic} \mathrm{layer} \mathrm{was} \mathrm{collected} \mathrm{and} \mathrm{analyzed} \mathrm{by} \mathrm{gas}$ chromatography (GC) to determine the composition and mass distribution of the oligomers.

\section{Conclusions}

A series of N-(2,2-dimethyl-1-(quinolin-2-yl)propylidene) aryliminonickel bromides have been synthesized and characterized. Four of the nickel complexes performed good activities for ethylene oligomerization, and both the variation of the substituents of the ligands and the reaction parameters affected the catalytic behaviors. The catalytic activities decreased on changing the reaction temperature to either lower or higher that the optimum temperature, consistent with the changes in run time. The Ni/EASC system showed high catalytic activity up to $4.06 \times 10^{6} \mathrm{~g} \mathrm{~mol}^{-1}(\mathrm{Ni}) \mathrm{h}^{-1}$, while the $\mathrm{Ni} / \mathrm{MMAO}$ system exhibited good characterization of ethylene trimerization. Compared with our 
previous 2-(1-aryliminoethylidene) quinolylnickel precatalysts [21], the gem-dimethylated title nickel complexes displayed higher activities as well as more hexenes. In summary, this illustrates the importance of finely tailoring the substituents affecting catalytic performances of metal complexes as well as the resultant oligomers.

Acknowledgments: This work was supported by National Natural Science Foundation of China (No. U1362204 and No. 21374123).

Author Contributions: H.S. and T.Z conducted synthesis and catalysis; Y.W. analysized some of compounds; Q.B. and W.H.S. supervised the research and wrote the manuscript.

Conflicts of Interest: The authors declare no conflict of interest.

\section{References}

1. Johnson, L.K.; Killian, C.M.; Brookhart, M. New Pd(I1)-and Ni(I1)-based batalysts for polymerization of ethylene and $\alpha$-olefins. J. Am. Chem. Soc. 1995, 117, 6414-6415. [CrossRef]

2. Keim, W.; Kowaldt, F.H.; Goddard, R.; Kruger, C. Novel coordination of (benzoy1methylene) triphenylphosphorane in a nickel oligomerization catalyst. Angew. Chem. Int. Ed. Engl. 1978, 17, 466-467. [CrossRef]

3. Ittel, S.D.; Johnson, L.K.; Brookhart, M. Late-metal catalysts for ethylene homo-and copolymerization. Chem. Rev. 2000, 100, 1169-1203. [CrossRef] [PubMed]

4. Britovsek, G.J.P.; Gibson, V.C.; Wass, D.F. The search for new-generation olefin polymerization catalysts: Life beyond metallocenes. Angew. Chem. Int. Ed. 1999, 38, 428-447. [CrossRef]

5. Wang, S.; Sun, W.-H.; Redshaw, C. Recent progress on nickel-based systems for ethylene oligo-/polymerization catalysis. J. Organomet. Chem. 2014, 751, 717-741. [CrossRef]

6. Schmid, M.; Eberhardt, R.; Klinga, M.; Leskela, M.; Rieger, B. New $C_{2 V}$-and chiral $C_{2}$-symmetric olefin polymerization catalysts based on nickel(II) and palladium(II) diimine complexes bearing 2,6-diphenyl aniline moieties: Synthesis, structural characterization, and first insight into polymerization properties. Organometallics 2001, 20, 2321-2330. [CrossRef]

7. Zou, H.; Zhu, F.; Wu, Q.; Ai, J.; Lin, S.A. Synthesis of long-chain-branched polyethylene by ethylene homopolymerization with a novel nickel(II) $\alpha$-diimine catalyst. J. Polym. Sci. Part A Polym. Chem. 2005, 43, 1325-1330. [CrossRef]

8. Liu, H.; Zhao, W.; Yu, J.; Yang, W.; Hao, X.; Redshaw, C.; Chen, L.; Sun, W.-H. Synthesis, characterization and ethylene polymerization behavior of nickel dihalide complexes bearing bulky unsymmetrical $\alpha$-diimine ligands. Catal. Sci. Technol. 2012, 2, 415-422. [CrossRef]

9. Jia, D.; Zhang, W.; Liu, W.; Wang, L.; Redshaw, C.; Sun, W.-H. Unsymmetrical $\alpha$-diiminonickel bromide complexes: Synthesis, characterization and investigation of their catalytic behavior toward ethylene. Catal. Sci. Technol. 2013, 3, 2737-2745. [CrossRef]

10. Rhinehart, J.L.; Brown, L.A.; Long, B.K. A robust Ni(II) $\alpha$-;diimine catalyst for high temperature ethylene polymerization. J. Am. Chem. Soc. 2013, 135, 16316-16319. [CrossRef] [PubMed]

11. Chen, Y.; Du, S.; Huang, C.; Solan, G.A.; Hao, X.; Sun, W.-H. Balancing high thermal stability with high activity in diaryliminoacenaphthene-Nickel(II) catalysts for ethylene polymerization. J. Polym. Sci. Part A Polym. Chem. 2017, 55. [CrossRef]

12. Wang, X.; Fan, L.; Yuan, Y.; Du, S.; Sun, Y.; Solan, G.A.; Guo, C.; Sun, W.-H. Raising the N-aryl fluoride content in unsymmetrical diaryliminoacenaphthylenes as a route to highly active Nickel(II) catalysts in ethylene polymerization. Dalton Trans. 2016, 45, 18313-18323. [CrossRef] [PubMed]

13. Laine, T.V.; Piironen, U.; Lappalainen, K.; Klinga, M.; Aitola, E.; Leskelä, M. Pyridinylimine-based nickel(II) and palladium(II) complexes: Preparation, structural characterization and use as alkene polymerization catalysts. J. Organomet. Chem. 2000, 606, 112-124. [CrossRef]

14. Jie, S.; Zhang, D.; Zhang, T.; Sun, W.-H.; Chen, J.; Ren, Q.; Liu, D.; Zheng, G.; Chen, W. Bridged bis-pyridinylimino dinickel(II) complexes: Syntheses, characterization, ethylene oligomerization and polymerization. J. Organomet. Chem. 2005, 690, 1739-1749. [CrossRef]

15. Yue, E.; Zhang, L.; Xing, Q.; Cao, X.P.; Hao, X.; Redshaw, C.; Sun, W.-H. 2-(1-(2-Benzhydrylnaphthylimino) ethyl)pyridylnickel halides: Synthesis, characterization, and ethylene polymerization behavior. Dalton Trans. 2014, 43, 423-431. [CrossRef] [PubMed] 
16. Yu, J.; Zeng, Y.; Huang, W.; Hao, X.; Sun, W.-H. N-(5,6,7-Trihydroquinolin-8-ylidene)arylaminonickel dichlorides as highly active single-site pro-catalysts in ethylene polymerization. Dalton Trans. 2011, 40, 8436-8443. [CrossRef]

17. Yu, J.; Hu, X.; Zeng, Y.; Zhang, L.; Ni, C.; Hao, X.; Sun, W.-H. Synthesis, characterization and ethylene oligomerization behaviour of $N$-(2-Substituted-5,6,7-trihydroquinolin-8-ylidene)arylaminonickel dichlorides. New J. Chem. 2011, 35, 178-183. [CrossRef]

18. Zhang, L.; Hao, X.; Sun, W.-H.; Redshaw, C. Synthesis, characterization and ethylene polymerization behavior of 8-(nitroarylamino)-5,6,7-trihydroquinolylnickel dichlorides: Influence of the nitro group and impurities on catalytic activity. ACS Catal. 2011, 1, 1213-1220. [CrossRef]

19. Sun, Z.; Yue, E.; Qu, M.; Oleynik, I.V.; Oleynik, I.I.; Li, K.; Liang, T.; Zhang, W.; Sun, W.-H. 8-(2-Cycloalkylphenylimino)-5,6,7-trihydroquinolylnickel halides: Polymerizing ethylene to highly branched and lower molecular weight polyethylenes. Inorg. Chem. Front. 2015, 2, 223-227. [CrossRef]

20. Huang, C.; Zhang, Y.; Liang, T.; Zhao, Z.; Hu, X.; Sun, W.-H. Rigid geometry 8-arylimino-7,7-dimethyl-5, 6-dihydroquinolyl nickel bromides: Single-site active species towards ethylene polymerization. New J. Chem. 2016, 40, 9329-9336. [CrossRef]

21. Song, S.; Zhao, W.; Wang, L.; Redshaw, C.; Wang, F.; Sun, W.-H. 2-(1-Aryliminoethylidene)quinolylnickel(II) dibromides: Synthesis, characterization and ethylene dimerization capability. J. Organomet. Chem. 2011, 696, 3772-3778. [CrossRef]

22. Hao, P.; Song, S.; Xiao, T.; Li, Y.; Redshaw, C.; Sun, W.-H. Highly active 8-benzoxazolyl-or 8-benzothiazolyl-2alkylquinolinylnickel(II) complexes for ethylene dimerization and vinyl polymerization of norbornene. Polyhedron 2013, 52, 1138-1144. [CrossRef]

23. Sun, W.-H.; Zhang, S.; Jie, S.; Zhang, W.; Li, Y.; Ma, H.; Chen, J.; Wedeking, K.; Fröhlich, R. Synthesis, characterization and ethylene oligomerization studies of nickel complexes bearing 2-imino-1,10-phenanthrolines. J. Organomet. Chem. 2006, 691, 4196-4203. [CrossRef]

24. Zhang, Y.; Huang, C.; Wang, X.; Mahmood, Q.; Hao, X.; Hu, X.; Guo, C.Y.; Solan, G.A.; Sun, W.-H. Highly branched unsaturated polyethylenes achievable using strained imino-cyclopenta[b]pyridyl-nickel precatalysts. Polym. Chem. 2017, 8, 995-1005. [CrossRef]

25. Huang, F.; Sun, Z.; Du, S.; Yue, E.; Ba, J.; Hu, X.; Liang, T.; Galland, G.B.; Sun, W.-H. Ring-tension adjusted ethylene polymerization by aryliminocycloheptapyridylnickel complexes. Dalton Trans. 2015, 44, 14281-14292. [CrossRef]

26. Sun, Z.; Huang, F.; Qu, M.; Yue, E.; Oleynik, I.V.; Oleynik, I.I.; Zeng, Y.; Liang, T.; Li, K.; Zhang, W.; et al. Targeting polyethylene waxes: 9-(2-Cycloalkylphenylimino)-5,6,7,8-tetrahydrocyclo heptapyridylnickel halides and their ethylene polymerization. RSC Adv. 2015, 5, 77913-77921. [CrossRef]

27. Sun, W.-H.; Zhang, W.; Gao, T.; Tang, X.; Chen, L.; Li, Y.; Jin, X. Synthesis and characterization of $\mathrm{N}$-(2-pyridyl)benzamide-based nickel complexes and their activity for ethylene oligomerization. J. Organomet. Chem. 2004, 689, 917-929. [CrossRef]

28. Tang, X.; Zhang, D.; Jie, S.; Sun, W.-H.; Chen, J. Nickel(II) complexes bearing phosphinooxazoline ligands: Synthesis, structures and their ethylene oligomerization behaviors. J. Organomet. Chem. 2005, 690, 3918-3928. [CrossRef]

29. Zhang, T.; Sun, W.-H.; Li, T.; Yang, X. Influence of electronic effect on catalytic activity of bis(imino)pyridyl Fe(II) and bis(imino)pyrimidyl Fe(II) complexes. J. Mol. Catal. A Chem. 2004, 218, 119-124. [CrossRef]

30. Liu, J.; Zheng, Y.; Li, Y.; Pan, L.; Li, Y.; Hu, N. Fe(II) and Co(II) pyridinebisimine complexes bearing different substituents on ortho-and para-position of imines: Synthesis, characterization and behavior of ethylene polymerization. J. Organomet. Chem. 2005, 690, 1233-1239. [CrossRef]

31. Song, S.; Xiao, T.; Liang, T.; Wang, F.; Redshaw, C.; Sun, W.-H. Synthesis, characterization and ethylene oligomerization behaviour of 8-(1-aryliminoethylidene)quinaldinylnickel dihalides. Catal. Sci. Technol. 2011, 1, 69-75. [CrossRef]

Sample Availability: Samples of the organic compounds and nickel complexes are available from the authors.

(C) 2017 by the authors. Licensee MDPI, Basel, Switzerland. This article is an open access article distributed under the terms and conditions of the Creative Commons Attribution (CC BY) license (http:/ / creativecommons.org/licenses/by/4.0/). 